\title{
One pandemic - four stories: Modelling the reality in British, American, Australian and Indian headlines
}

\author{
T. A. Chaiuk*, K. S. Karpova \\ Taras Shevchenko National University of Kyiv \\ *Corresponding author. Email: chajuk.t@gmail.com
}

Paper received 14.02.21; Accepted for publication 23.02.21.

\section{https://doi.org/10.31174/SEND-Ph2021-248IX73-05}

\begin{abstract}
The article examines headlines of online media from the United Kingdom, the United States of America, Australia and India, published in January, 2021, in order to reconstruct models of the 'pandemic reality' shaped by these titles in their audiences. The analysis reveals that each of the media builds a peculiar model, which is achieved by focusing on specific aspects of the pandemic, such as its global or national scope, by linking medical and political issues, and by drawing on certain metaphors.
\end{abstract}

Keywords: headline, pandemic, metaphor, model of reality, conceptualization.

Introduction. The world underwent considerable changes in 2020: the coronavirus pandemic seems to have affected both individuals and nations. In 2020, national economies experienced a severe blow, retail switched to online, companies were forced to reconsider their employment policies, travelling became problematic due to stringent restrictions. Citizens watched their freedoms and liberties taken away by governments: lockdowns in many countries prohibited gatherings and even getting out of one's home. As a result, the tendencies in interpersonal communication that started to develop in the $21^{\text {st }}$ century accelerated: people shifted to the online mode of managing their social lives and the phone finally yielded its leading position to social media and online platforms, which brought about numerous new lexemes (see, for example, [4]).

Just like patterns and media of interpersonal contacts, mass communication started changing since the beginning of the $21^{\text {st }}$ century: mass media have been going more and more digital at the expense of publishing. And the lockdown sped up the decline of printed newspapers [20] (also see [17]). Confined to their houses and used to receiving news every day, mass media audiences have no other option but to surf the net and access online versions of their favourites. Those who have no habit of reading newspapers join the newspaper audience either because the lockdown has provided them with more time to spare or because they feel too anxious in this new reality of restrictions and fear. As a result, just as printed newspapers have gradually become a thing of the past, the number of online readers has been on the rise and 2020 accelerated its growth [20;27].

The pandemic has made online news media an important source of information: in the situation of physical isolation, online media have become the window onto the world. What is more important, however, is that online media are an effective tool to channel their audiences' thoughts and to shape their representation of reality. The research shows that media coverage distinguishes a seemingly important topic among a number of other news items, keeps the audience's attention on this particular topic and turns it into a conspicuous issue in the public sphere (for more details, see $[9 ; 10])$. Therefore, the high frequency of occurrence in media publications brings a topic to the core of public discourse, i.e., the public is manipulated into thinking of it as well as into WHAT to think of. Techniques used to verbalise the topic (lexical means and their connotations, syntax, and stylistic devices) manipulate the public into HOW to think of this topic [12, p.52-53]. Thus, analysis of texts uploaded by online media on a certain topic facilitates understanding the representation of reality these media outlets try to create for their audiences.

Literature review. News discourse has been attracting researchers' attention for a long time, News as discourse by van Dijk [24] being among the fundamental studies. In this publication, the scholar establishes the study of news as a field of research: he explores a news article as a product, i.e., from the point of view of its structure, and suggests a news schema. He also explores a news article as a process: he analyses news production and comprehension, which brings him to the conclusion that the elements of the news schema "have cognitive and social functions in news production and in news understanding and memorization" [24, p.188].

Van Dijk argues that the headline is an obligatory element of any news article and "expresses a macroproposition" [24, p.36]. The function of the headline lies in signalling a topic and being, in fact, a summary of the article that follows [24, p.35-36]. According to the researcher, when reading a news article, one first concentrates on its headline since understanding the headline is the first stage of decoding and interpreting further information [24, p.143]. Decoding headlines is viewed as a cognitive process that draws on activating relevant concepts and knowledge frames, which condition the reader's further actions: first, the reader may decide to continue reading the article or skip it and, second, the reader is "primed" to a certain interpretation of the text [24, p.143]. Since headlines are not complete sentences and may be opaque, "much processing is left over to semantic interpretation" and this makes their analysis "not so much syntactic as conceptual" [24, p.144]. In other words, headlines may be understood and interpreted only if one has an appropriate knowledge frame (or script, or model) to lean on. The immense significance of headlines for the reader's choice, understanding and interpretation is completed with its exceptional importance for memorization: "the information in headlines... tends to be best recalled both in immediate and delayed recall. For the average reader, such knowledge does not seem to be highly developed and complex, but rather of the headline type" $[24$, p.170].

The research into news discourse received a new momentum when the media gradually started moving online. The Internet has changed the audience's strategies and reading habits and brought the significance of headlines to an even higher level. As research shows, bombarded with 
volumes of accessible information, online readers would rather scroll news feeds than go beyond headlines. In other words, the full content is not read, which makes headlines the basis of one's opinion and reaction to an issue, though some headlines may be misleading or give a biased point of view $[17$, p. 1,8$]$.

As we can see, researching media discourse involves applying a multidisciplinary approach that merges linguistics, cognitive science, sociology, psychology, and communication studies. Headlines in particular have been explored from various perspectives. Thus, linguists have analysed syntactic features of news headlines and produced purely linguistic research [22]. Other studies apply Critical Discourse Analysis and correlate language peculiarities of news titles with persuasion and ideology $[2 ; 3 ; 6 ; 11 ; 23]$. As a result, the scholars conclude that headlines deliver implicit ideological meanings that serve interests of certain social groups. Hence, the researchers argue that headlines successfully fluctuate between the function of informing their audience and the function manipulating the audience into developing certain views on social, political, or economic phenomena (see, for example, [21]).

Importantly, a number of scholars use contrastive analysis to explore media of different countries, which produces revealing results and sheds light on the ideological and manipulative functions of newspapers in general and headlines in particular $[15 ; 21]$.

In this context, it is worth mentioning that some scholars suggest the term 'headlinese' [13]. According to this approach, 'headlinese' is a genre, yet mostly occurring in the UK and English-speaking countries influenced by Britain (Australia, Canada, New Zealand, and India). Isani argues that though 'headlinese' is not a culture-specific genre, yet it is much less observable in French, German, and Italian media.

Since the coronavirus pandemic has already been shaking the world for a year keeping mass media abundant in pandemic-related publications, these articles attract schol- ars' attention. For example, media discourse of the coronavirus pandemic is discussed by Chaiuk and Dunaievska [8] whose material embraces the period of January - March 2020. The research reveals that publications in British and American online media of that time verbalised and escalated anxiety, which resulted in production of fear culture. A similar study on the panic-arousing role of media, belongs to Ilchuk and Petryshyna who conducted their research on the material of the Ukrainian press [1]. The study of Ukrainian pandemic-related headlines shows that negative components dominate at the expense of neutral ones. The scientists ascribe this tendency to journalists' attempts to attract larger audiences with sensational titles as well as to cultivate certain social norms [1, p.90].

In his report delivered in May 2020, Atasoy analyses representations of the COVID-19 pandemic in headlines of the two leading German and Spanish newspapers, Süddeutsche Zeitung and El Pais [5]. The researcher notes that the headlines convey not only the COVID-19 agenda, but also, by strategically reiterating particular lexemes, reinforce the hidden ideology that emphatically pictures China as source of the global health crisis. Another noteworthy feature of the headlines is including death and case statistics. These observations enable Atasoy to argue that the German and the Spanish newspapers "prefer to use fear as a decisive factor. Fear of death is almost simultaneously dampened through othering" [5, p.4]

The objective of the research is to analyse headlines of online articles on the coronavirus pandemic in four English-speaking countries, the UK, the USA, Australia and India, in order to explore the representation of the pandemic and the reality shaped by these media in each of the countries.

Material and methods. The corpus comprises 143 headlines collected through continuous sampling in January, 2021, from the section titled CORONAVIRUS on sites of British, US, Australian and Indian online media. For more details on the sample, see the table below:

Sample: sources and timespan

\begin{tabular}{|c|c|c|c|c|}
\hline$\#$ & Name of media & Country & Number of headlines & Timespan \\
\hline 1 & BBC & United Kingdom & 24 & Jan 5 - Jan 27, 2021 \\
\hline 2 & The Washington Post & USA & 24 & Jan 5 - Jan 27, 2021 \\
\hline 3 & The New Daily & Australia & 45 & Jan 10 - Jan 27, 2021 \\
\hline 4 & The Tribune & India & 50 & Jan 15 - Jan 27, 2021 \\
\hline
\end{tabular}

The methods applied to the sample include content analysis, componential analysis, and conceptual analysis. The final stage of the study is based on Critical Discourse Analysis (van Dijk 2013, 2015).

Results. The health challenge of 2020 has had its effect on the English language. This may be seen from the words that have been nominated "The World of the Year" by English dictionaries. Thus, the data of Merriam-Webster's Dictionary on word frequency put 'pandemic' as the word of the year 2020 [16]. The Cambridge Dictionary crowns 'quarantine' as Word of the Year and argues that 'quarantine' 'has defeated 'lockdown' and 'pandemic'... after data showed it to be one of the most highly searched for on the Cambridge Dictionary" [7].

The Oxford Dictionary is not so quick to suggest the word of 2020 pointing out that "2020 is not a year that could neatly be accommodated in one single "word of the year"' and issuing the Words of an Unprecedented Year report to explore in more details "the phenomenal breadth of language change and development over the year" [19]. The report does show that the English-speaking community was at times distracted from the pandemic and was preoccupied with the Black Lives Matter movement and the US presidential elections, yet the pandemic-related words kept on resurfacing as the top hits throughout the year 2020: coronavirus in March, Covid-19 and lockdown in April, social distancing in May followed by reopening in May June, moonshot in September, and superspreader in October [19, p.1-2].

The Words of an Unprecedented Year report is noteworthy because it shows that the concept pandemic is complex and, in fact, signifies a dynamic phenomenon that consists of stages endowed with particular key elements. These elements are the name of a virus, the name of a disease the virus causes as well as governmental policies employed to curb its spreading. Yet, national governments turn to differ- 
ent measures to cope with the health crisis and nations react differently to the threat and the new policies, so the focus of attention verbalised by a word may be difficult to generalize not only because of the timespan: the global pandemic may be conceptualised differently in different regions of the world even under the condition of simultaneity.

The preliminary study of the British, US, Australian and Indian online media headlines published in January 2021, reveals that all the four offer their audiences, along with Home, News, Opinion, Culture, Weather, etc., a separate section titled Coronavirus.

Further research uncovers, however, considerable differences that start, first of all, from a formal feature, namely the spelling of the acronym that stands for the coronavirus disease of 2019, COVID-19. Thus, BBC site capitalizes the first letter of the acronym - Covid, while the Washington Post prefers coronavirus (15 cases) and writes about covid in two cases without any capitalisation. Australian New Daily capitalises every letter of the acronym COVID as if it were an abbreviation, and Indian Tribune alternates between Covid and COVID. Therefore, the headlines reveal lack of standardization that is not surprising taking into account the speed with which the medical term took over public discourse.

A look into the content of each of the sites yields the following results.

1. $\mathrm{BBC}$ arranges the information in the Coronavirus sections by dividing the material into two subsections: Coronavirus Pandemic (made up of Coronavirus Explained and Advice and Support) and Your Coronavirus Stories (comprising Get in Touch with Us and Life in Lockdown). In other words, the arrangement suggests that the pandemic is of a global scale, yet it has also a personal dimension and readers are invited to participate by sending their own story.

The content analysis of the BBC headlines reveals that they tend to contain negatively connoted vocabulary (catastrophic failure, challenge, fears, fight, prison, to scare) and lexemes that verbalise the concept of death (death, to die, to kill).

Six BBC headlines contain proper names of politicians and countries alongside medical terms, which implies that international and national politics has merged with health care issues:

Biden signs more executive orders in Covid fight

Biden's coronavirus challenge

Hungary first in $\boldsymbol{E} \boldsymbol{U}$ to approve Russian vaccine

Covid-19's impact on Israel

Australia 'unlikely to fully open border in 2021'

Indonesia coronavirus vaccination drive targeting younger people.

Nine headlines focus the readers' attention on the issue of vaccination:

Israel vaccine fears 'out of context and inaccurate'

Shocked to be Europe's vaccination straggler,

What's the problem with the EU's vaccine programme?

The differences between the Covid vaccines explained.

The sample also contains 11 headlines that depict the bleak life during the lockdown (e.g., When home is both prison and sanctuary; Lockdown when love of your life is in a care home). The gloomy life of today is emphatically contrasted with joyful and fulfilling pre-corona times, which is verbalised by references to the past as well as the adjectives new and old:

Recordings show lockdown London quieter than 1928

'The new normal scared me'

Will a vaccine give us our old lives back?

While the present covered on the BBC Coronavirus page is dark compared to the past, the looming future, outlined in two headlines of the sample, is unlikely to be brighter. In World on the brink of catastrophic moral failure - WHO, there is a prediction of a global disaster, the likelihood of the prediction being boosted by the reference to the World Health Organisation. The headline Can we really jab our way out of lockdown? draws on an interrogative sentence transformed by really into a rhetorical question with implied negation.

2. The Washington Post's headlines also show a strong tendency to use lexemes with negative connotations: though there are occasional verbalisers of the death concept (to die (once) and deaths (twice)), the warfare vocabulary dominates and includes such lexemes as battle, to jeopardize, struggle, to survive, to threaten, violence.

The Washington Post's Coronavirus section offers readers a complicated model of reality. Thus, nine headlines imply the globality pandemic-related issues: they occur in the USA and in other parts of the world:

Inside this California hospital, a 'constant battle' against covid-19

Philadelphia let 'college kids' distribute vaccines. The result was a 'disaster', volunteer said

What to know about the coronavirus vaccine rollout in D.C., Maryland and Virginia

Netherland,

Three nights of anti-lockdown violence in the

E.U. threatens drug companies with legal action if it doesn't get its vaccines.

The US media visualises the pandemic in America and worldwide by providing audiences with maps: US coronavirus cases and state maps: Tracking cases, deaths and Mapping the worldwide spread of the coronavirus.

The Washington Post pays little attention to educating their readers about the virus itself (only one headline: What you need to know about the coronavirus variants) but gives much attention to the vaccination process (11 headlines). Seven of these present vaccination as a medical issue:

Large majorities of the region's nursing home workers have declined the coronavirus vaccine

A day in the hospital as it receives its first coronavirus vaccines.

Four headlines link vaccination and their delivery with politics by presenting either politicians or state bodies as agents in the process of purchasing or distributing vaccines:

House opens investigation of pandemic ventilator purchases overseen by White House;

Coronavirus updates: E.U. feud with vaccine maker bursts into the open as Biden promises more doses for U.S.;

Biden administration seeks to buy 200 million more vaccine doses, to be delivered through the summer.

Other aspects of the pandemic that receive some coverage are everyday life (e.g., The coronavirus pandemic in the voices of those who lived it; Living on the brink: One family's struggle to survive the pandemic) and the disrupted schooling (The battle over reopening schools; Teachers are moving to the front of the vaccine line - but that 
doesn't mean all schools will reopen right away; CDC finds scant spread of coronavirus in schools with precautions in place).

3. Content analysis of 45 Australia's New Daily headlines reveals such lexemes and word combinations as restrictions (used 6 times), to ease (5 times), to relax (2 times), fines (2 times), to suspend, limits, rules, breaches. The headlines that inform of new regulations make up 13 items, nine being about loosening the restrictions, two about tightening them up or keeping unchanged and two on breaches of quarantine rules:

$N S W$ relaxes gathering limits, mask restrictions, Quarantine-free NZ travel bubble suspended, Coronavirus restrictions easing for Greater Bris-

bane.

Though there are headlines that cover the situation in the world, yet they are only four (e.g., Indonesia passes one million coronavirus cases, Biden tackles pandemic on day one in office, Mutated virus strain may be more deadly: Johnson) and these are the only titles that contain negatively-connoted lexemes fears, deadly, deeply sorry.

Five of The New Daily's headlines provide readers with statistics, yet the statistics is on coronavirus cases or their absence, not on deaths (Vic hits 20 days with no local coronavirus cases, Two new virus cases in Queensland quarantine, Vic records four new COVID cases in quarantine).

The topic of vaccination is highlighted in five headlines (No jumping vaccine queue, say top athletes; $\$ 24 m$ ad campaign to encourage COVID jabs) and three feature the Australian Open tournament due to be held on February 8 February 21 (Australian Open hit by new lockdowns and breaches).

4. The Indian Tribune aims primarily at informing its audience of statistics: 33 out of 50 headlines report on the number of coronavirus cases and deaths across India, using various verbalisers of DEATH concept on 20 occurrences:

No deaths, 47 positive in Ludhiana

1 dead, 63 test +ve in Jammu and Kashmir

5 succumb, 120 cases in Haryana

Four die, 136 fresh cases in Haryana

Covid-19: 32 fresh cases, one fatality in Chandigarh.

Interestingly, the examples contain the substantivised adjective positive (i.e., people whose PCR tests show positive results) and its synonym test $+v e$, where the mathematical symbol + signifies the lexical meaning and ve stands for an adjective marker.

The topic of vaccination comes second: 12 headlines inform the readers of India's progress in vaccination using such lexemes as vaccine, vaccination, to vaccinate, to inoculate, inoculation, COVID jab, and Covaxin shot (e.g., Covid vaccination drive picks up pace in Amritsar district; 6.186 get inoculated in Haryana; Covaxin shots 'effusive' against new UK strain).

There are only four headlines that provide their readers with a bigger picture: e.g., UK hits grim COVID-19 death toll figure of 100 000; Stop hoarding COVID vaccines, South Africa's Ramaphose tells rich countries.

Discussion. The headlines of four online media located in the UK, the USA, Australia and India, display both linguistic and conceptual differences in their coverage of the coronavirus pandemic in January, 2021. The linguistic difference stems from lack of a standardized spelling of the coronavirus disease: in the acronym Covid, the first letter may be little or capitalized or all the letters may be capital as in abbreviations.

As for the conceptualisation of the pandemic, the British, US, Australian and Indian online media headlines of the sample focus their audiences on different aspects of the health crisis and, therefore, construct for their readers four different models of reality.

Thus, the BBC headlines contain the vocabulary of global disaster and lead their audiences to 'catastrophic thinking', where, for the world in general and for a British citizen in particular, the past seems to be happy times, the present is grim, and the future can hardly show much improvement.

The US headlines draws on the metaphor of the global and national struggle with the coronavirus where the resolution of the health crisis (in January 2021, the challenge lies in organising the vaccination process) is tightly bound with politics.

The Australian New Daily is more localized and 'inward-looking': it focuses on Australia's inner policies and models the reality where the country is successfully coping with the pandemic: the restrictions imposed in March, 2020, are being eased and the statistics shows positive dynamic.

The headlines of India's Tribune highlight two aspects of the pandemic and do this in the analytic way: they provide the audience, first, with statistics on test positive people and deaths and, second, on the vaccination process, thus modelling the reality in terms of 'lethal disease - preventive method'.

Conclusion. The research reveals that, though the coronavirus pandemic is observed in all of the four countries whose media have been chosen for the analysis and though the countries are passing through the same stage in handling this health challenge, in each country, the media headlines build for their readers a specific model of the 'pandemic reality' by focusing attention on certain aspects of the pandemic (e.g., statistics, vaccination, psychological pressure of the lockdown), by connecting some processes (e.g., medical and political issues), and by developing certain metaphors (e.g., war or disaster).

\section{ЛІТЕРАТУРА}

1. Ільчук А. О., Петришина О. І. Що більше лякає українців: COVID-19 чи заголовки публікацій про пандемію? // Прикладна лінгвістика 2020: проблеми і рішення: Матеріали 16-ої Всеукраїнської науково-методичної конференції молодих науковців. Миколаїв: НУК, 2020. С. 87-90

2. Кузнецова О., Король Т. Чинники психологічного впливу заголовків львівських газет "Високий замок”, "Експрес", "Ратуша" // Вісник національного університету «Львівська політехніка». Серія «Журналістські науки». 2020. №4.

C.53-62. Doi: doi.org/10.23939/sjs2020.01.053

3. Скрябіна В. Актуалізація ціннісних орієнтирів у заголовках англомовних та україномовних інтернет-новин // Актуальні питання гуманітарних наук. Сер. Мовознавство. Літературознавство. 2020. Вип. 26. Т.4. С. 10-16

4. Alyeksyeyeva I.O., Chaiuk T.A., Galitska E.A. Coronaspeak as Key to Coronaculture: Studying New Cultural Practices through Neologisms // International Journal of English Linguistics. 2020. Vol.10 (6). P. 202-212. Doi: 10.5539/ijel.v10n6p202 
5. Atasoy I. Representations of the COVID-19 Pandemic in German and Spanish Newspaper Headlines: A Comparative Analysis. Mode of access https://www.researchgate.net/publication/341679013_Represen tations_of_the_COVID-

19_Pandemic_in_German_and_Spanish_Newspaper_Headline s_A_Comparative_Analysis

6. Bedu A. M. Ideological Relevance of Nominalization and Lexicalization in Nigerian Newspapers' Editorials and their Headlines // Maiduguri Journal of Linguistic and Literary Studies. 2016. V. xiii. P.15-27

7. Cambridge Dictionary names 'quarantine' Word of the Year $2020 . \quad$ Mode of access https://www.cam.ac.uk/research/news/cambridge-dictionarynames-quarantine-word-of-the-year-2020

8. Chaiuk T. A., Dunaievska, O. V. Producing the Fear Culture in Media: An Examination on Coronavirus Discourse // Journal of History Culture and Art Research. 2020. Vol. 9(2). P. 184-194. doi:http://dx.doi.org/10.7596/taksad.v9i2.2636

9. Daddow O. The UK media and Europe: from permissive consensus to destructive dissent // International Affairs. 2012. Vol. 88(6). P. 1219-1236.

10. De Freitas, W. Coronavirus: how media coverage of epidemics often stokes fear and panic // The Conversation. 2020. Retrieved from https://theconversation.com/coronavirus-howmedia-coverage-of-epidemics-often-stokes-fear-and-panic131844

11. Fuertes-Olivera P. A., Velasco-Sacristán M., Arribas-Baño A., \& Samaniego Fernández E. Persuasion and advertising English: Metadiscourse in slogans and headlines // Journal of Pragmatics. 2001. \#33. P.1291-1307

12. Furedi, F. Culture of Fear. Risk-Taking and the Morality of Low Expectation. London, New York: Continuum, 2020.

13. Isani S. Of headlines \& headlinese: Towards distinctive linguistic and pragmatic genericity // ASp [Online], 60 | 2011, Online since 07 October 2014, connection on 30 September 2016. Mode of access: http://asp.revues.org/2523. DOI: https://doi.org/10.4000/asp.2523

14. Khalid P. Modality Analysis of the Newspaper Articles about the Scottish Ship RMS Queen Elizabeth // Academic Journal of Interdisciplinary Studies. 2013. Vol. 2(9). P. 458-461.

15. Magtira J. M. B., Bernardo A. S. A contrastive analysis of Filipino and American newspaper editorial headlines. 2017. Mode of access http://oaji.net/articles/2020/83071595889664.pdf

\section{ДЖЕРЕЛА ІЛЮСТРАТИВНОГО МАТЕРІАЛУ}

28. https://www.bbc.com/news/coronavirus

29. https://thenewdaily.com.au/news/coronavirus/
16. Merriam-Webster's Word of the Year. Mode of access https://www.merriam-webster.com/words-at-play/word-of-theyear/pandemic

17. Nwammuo A., Nwafor G. (2020). How Newspaper Headlines Sway Opinion: Analysis of Online Newspaper Readership Patterns among Facebook Users // International Journal of Informatics, Technology \& Computers. 2020. Vol. 5 (1). P.1-10.

18. Oxford Languages. (2020). Word of the Year 2020. Mode of access https://languages.oup.com/word-of-the-year/2020/

19. Oxford Languages. (2020). Words of an Unprecedented Year. Retrieved from https://pages.oup.com/ol/word-of-the-year2020

20. Rajan A. How coronavirus infected publishing // BBC. 2020. Mode of access https://www.bbc.com/news/entertainment-arts52299925

20. Share of individuals reading or downloading online news, newspapers or magazines in Great Britain from 2007 to 2020. Access

https://www.statista.com/statistics/286210/online-newsnewspapers-and-magazine-consumption-in-great-britain/

21. Sommella S. Terrorism in German and Italian Press Headlines // Quaderni di Linguistica e Studi Orientali / Working Papers in Linguistics and Oriental Studies. 2019. Vol. 5. P. 497-547. DOI: http://dx.doi.org/10.13128/QULSO-2421-7220-25979

22. Tabula R. V., Agbayani R. S. Syntactic Patterns of News Headlines in Philippine and American Newspapers // JPAIR Multidisciplinary Research. 2015. Vol. 22. P.44-58. Doi: http://dx.doi.org/10.7719/jpair.v22i1.335

23. Taiwo R. Language, Ideology and Power Relations in Nigerian Newspaper Headlines. 2007. Mode of access https://www.researchgate.net/publication/26456692_Language _Ideology_and_Power_Relations_in_Nigerian_Newspaper_He adlines

24. Van Dijk T.A. News as discourse. Hillsadle, NJ: Erlbaum Publishing, 1988.

25. Van Dijk T. Ideology and discourse // The Oxford Handbook of Political Ideologies. Oxford, UK: Oxford University Press, 2013. P. 175-196.

26. Van Dijk T. Critical Discourse Analysis // The Handbook of Discourse Analysis. Victoria, CA: Blackwell Publishing, 2015. P. $466-485$.

27. Waiting C. Newspaper readership is on the rise, and more consumers are paying for online news. 2021. Mode of access https://whatsnewinpublishing.com/newspaper-readership-is-onthe-rise-and-more-consumers-are-paying-for-online-news/
30. https://www.tribuneindia.com/news/coronavirus

31. https://www.washingtonpost.com/coronavirus

\section{REFERENCES}

1. Ilchuk A. O., Petryshyna O. I. What scares Ukrainians more: COVID-19 or publications on pandemic? // Prykladna lingvistika 2020: problemy I rishennia: Materials of the $16^{\text {th }}$ AllUkrainian scientific and methodological conference for young scientists. Mykolayiv: National University of Shipbuilding, 2020. P. 87-90.

2. Kuznetsova O., Korol T. Factors of psychological influence of headlines of newspapers "Vysokyy zamok", "Ekspres", "Ratu-

sha" // Visnyk natsionalnoho universytetu "Lvivska politekhnika". Seria: Journalism. 2020. \#4. P.53-62. Doi: doi.org/10.23939/sjs2020.01.053

3. Skriabina V. Values manifested in English-language and Ukrainian-language Internet-headlines // Aktualni pytannia humanitarnyh nauk. Seria Linguistics. Literary Studies. 2020. Issue. 26. Vol. 4. P. 10-16 